\title{
Galaxie des pédagogies alternatives en France
}

\section{Sylvain Wagnon et Hélène André}

\section{(2) OpenEdition \\ 12 Journals \\ Édition électronique \\ URL : http://journals.openedition.org/trema/4363 \\ DOI : $10.4000 /$ trema.4363 \\ ISSN : 2107-0997 \\ Éditeur \\ Faculté d'Éducation de l'université de Montpellier}

\section{Édition imprimée}

Date de publication : 1 novembre 2018

ISSN : 1167-315X

Référence électronique

Sylvain Wagnon et Hélène André, "Galaxie des pédagogies alternatives en France », Tréma [En ligne], 50 | 2018, mis en ligne le 09 novembre 2018, consulté le 04 mai 2019. URL : http://

journals.openedition.org/trema/4363; DOI : 10.4000/trema.4363

Ce document a été généré automatiquement le 4 mai 2019.

Trema 


\section{Galaxie des pédagogies alternatives en France}

Sylvain Wagnon et Hélène André

Galaxie des pédagogies alternatives en France

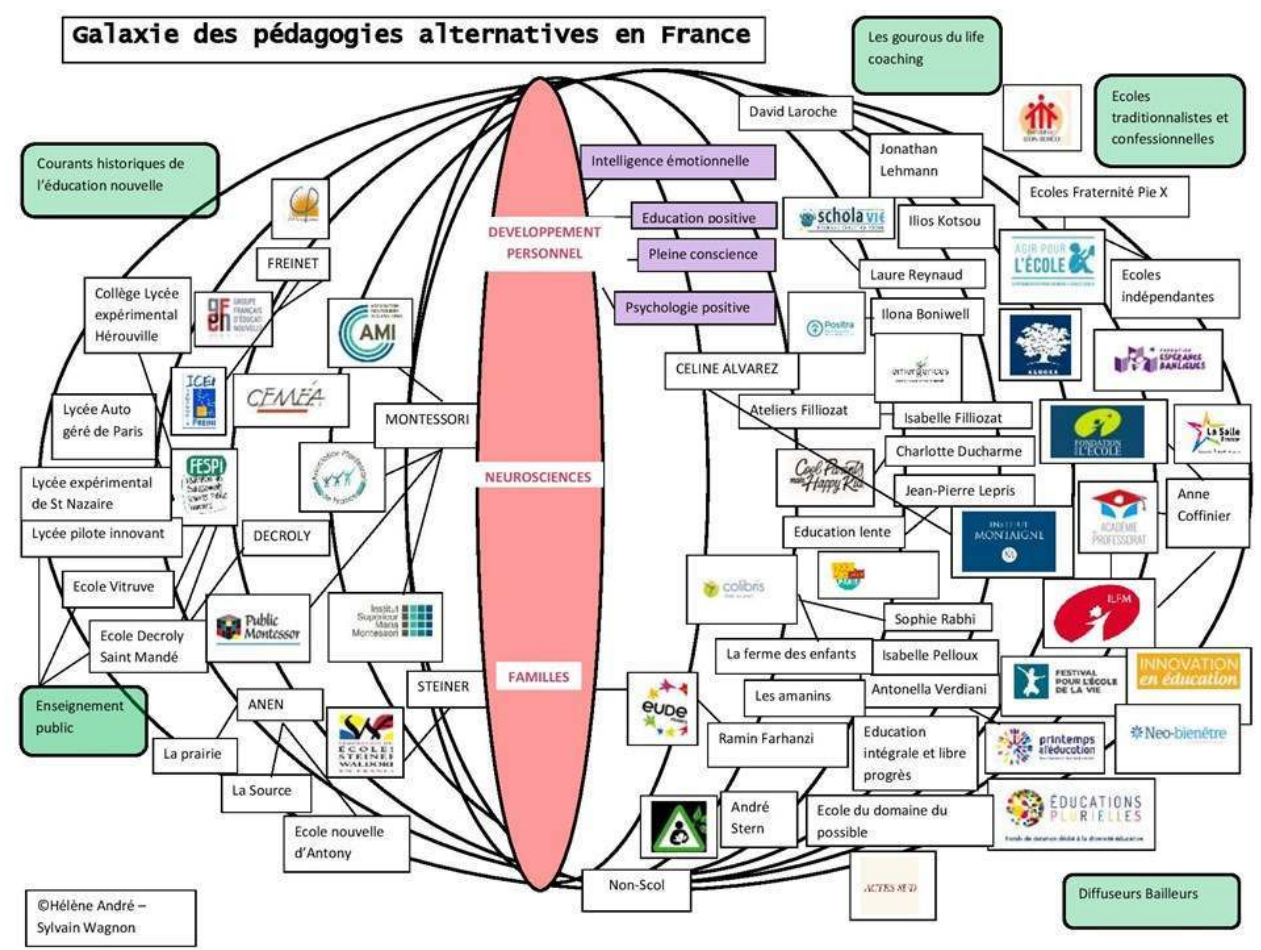




\section{RÉSUMÉS}

Une cartographie nous est apparue nécessaire pour expliciter la variété de la galaxie des pédagogies alternatives mais aussi pour analyser leurs caractéristiques et les ramifications entre les différents acteurs. Loin d'être exhaustive, cette cartographie n'est qu'une première étape d'une cartographie plus globale et internationale. Cette cartographie vient enrichir et éclairer les articulations, relations entre acteurs, mouvements mais aussi groupes de pression et lobbys qui gravitent à l'intérieur et à l'extérieur des pédagogies alternatives. Elle met l'accent sur différents archipels de cette galaxie ainsi que sur les pivots de cette nébuleuse (les familles, les neurosciences et la notion de développement personnel).

A cartography is necessary to explain the variety of the galaxy of the alternative pedagogies but also to analyze their characteristics and the ramifications between the different actors. This cartography is a first step for a global and international cartography. This cartography offers the articulations, relationships between actors, movements and lobbies of this galaxy. It focuses on different archipelagos of this galaxy as well as on the pivots of this nebula (families, neuroscience and the notion of personal development).

\section{INDEX}

Keywords : alternative pedagogies, mapping, neuroscience, personal development

Mots-clés : pédagogies alternatives, cartographie, neurosciences, développement personnel

\section{AUTEURS}

\section{SYLVAIN WAGNON}

LIRDEF, Université de Montpellier

\section{HÉLÈNE ANDRÉ}

CEDRHE, Université de Montpellier 